\title{
Adequacy of the 123-Group Cross-Section Library for Criticality Analyses of Water-Moderated Uranium Systems
}

Manuscript Completed: June 1995

Date Published: August 1995

Prepared by

C. V. Parks, R. Q. Wright, W. C. Jordan

Oak Ridge National Laboratory

Managed by Lockheed Martin Energy Systems

Oak Ridge National Laboratory

Oak Ridge, TN 37831-6370

Prepared for

Spent Fuel Office

Office of Nuclear Material Safety and Safeguards

U.S. Nuclear Regulatory Commission

Washington, DC 20555-0001

NRC Job Code B0009 


\section{DISCLAIMER}

This report was prepared as an account of work sponsored by an agency of the United States Government. Neither the United States Government nor any agency thereof, nor any of their employees, make any warranty, express or implied, or assumes any legal liability or responsibility for the accuracy, completeness, or usefulness of any information, apparatus, product, or process disclosed, or represents that its use would not infringe privately owned rights. Reference herein to any specific commercial product, process, or service by trade name, trademark, manufacturer, or otherwise does not necessarily constitute or imply its endorsement, recommendation, or favoring by the United States Government or any agency thereof. The views and opinions of authors expressed herein do not necessarily state or reflect those of the United States Government or any agency thereof. 


\section{DISCLAIMER}

Portions of this document may be illegible in electronic image products. Images are produced from the best available original document. 


\begin{abstract}
In a recent criticality analysis for an array of water-moderated packages containing highly enriched uranium, the 123group cross-section library in the SCALE system was observed to have a nonconservative discrepancy of

approximately 3 to $3.5 \%$ when compared with more recently developed libraries. A simple representative system of $\mathrm{UO}_{2} \mathrm{~F}_{2} \cdot \mathrm{H}_{2} \mathrm{O}$ was used to identify that the problem results from a lack of resonance data for ${ }^{235} \mathrm{U}$. Only a single set of self-shielded cross sections, most likely corresponding to a water-moderated infinite dilute system, was provided with the original data. The $\mathrm{UO}_{2} \mathrm{~F}_{2} \cdot \mathrm{H}_{2} \mathrm{O}$ study indicates that this limitation may cause nonconservative discrepancies as high as $5.5 \%$ for some water-moderated, highly enriched uranium systems. Characteristics of the systems where the discrepancy is evident are identified and discussed.
\end{abstract}





\section{CONTENTS}

Page

ABSTRACT $\ldots \ldots \ldots \ldots \ldots \ldots \ldots \ldots \ldots \ldots \ldots \ldots \ldots \ldots \ldots \ldots \ldots \ldots \ldots \ldots \ldots \ldots \ldots \ldots$

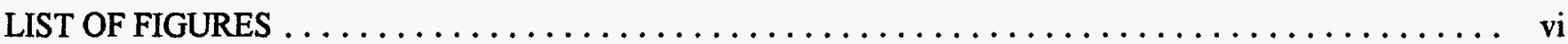

LIST OF TABLES $\ldots \ldots \ldots \ldots \ldots \ldots \ldots \ldots \ldots \ldots \ldots \ldots \ldots \ldots \ldots \ldots \ldots \ldots \ldots \ldots$

ACKNOWLEDGMENTS $\ldots \ldots \ldots \ldots \ldots \ldots \ldots \ldots \ldots \ldots \ldots \ldots \ldots \ldots \ldots \ldots \ldots \ldots \ldots$

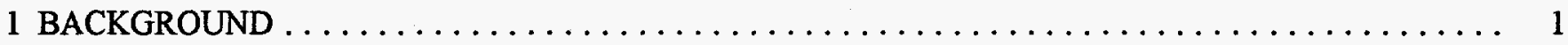

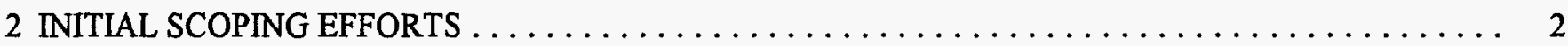

3 IDENTIFICATION OF THE PROBLEM $\ldots \ldots \ldots \ldots \ldots \ldots \ldots \ldots \ldots \ldots \ldots \ldots \ldots \ldots \ldots$

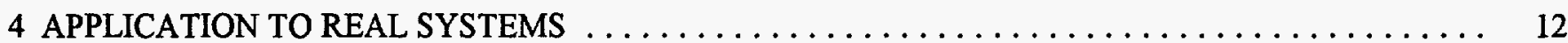

5 CONCLUSIONS AND RECOMMENDATIONS $\ldots \ldots \ldots \ldots \ldots \ldots \ldots \ldots \ldots \ldots \ldots \ldots \ldots \ldots$

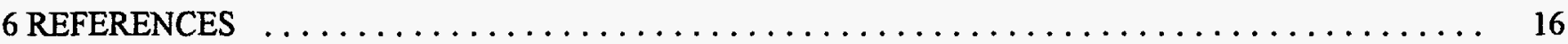




\section{LIST OF FIGURES}

Figure

$\underline{\text { Page }}$

3.1 XSDRNPM $k_{\infty}$ calculations for $\mathrm{UO}_{2} \mathrm{~F}_{2} \cdot \mathrm{H}_{2} \mathrm{O}$ systems

$3.2{ }^{235} \mathrm{U}$ fission cross section, $\mathrm{UO}_{2} \mathrm{~F}_{2} \cdot \mathrm{H}_{2} \mathrm{O}$ at an $\mathrm{H} / \mathrm{X}=10$

$3.3{ }^{235} \mathrm{U}$ fission cross section, $\mathrm{UO}_{2} \mathrm{~F}_{2} \cdot \mathrm{H}_{2} \mathrm{O}$ at an $\mathrm{H} / \mathrm{X}=10$

3.4 Flux using group data for highly enriched $\mathrm{UO}_{2} \mathrm{~F}_{2} \cdot \mathrm{H}_{2} \mathrm{O}$ systems at an $\mathrm{H} / \mathrm{X}=10$

3.5 Fission rate using group data for highly enriched $\mathrm{UO}_{2} \mathrm{~F}_{2} \cdot \mathrm{H}_{2} \mathrm{O}$ systems at an $\mathrm{H} / \mathrm{X}=10$

3.6 XSDRNPM $k_{\infty}$ calculations for $\mathrm{UO}_{2} \mathrm{~F}_{2} \cdot \mathrm{H}_{2} \mathrm{O}$ systems, $100 \%$ and $5 \%$ enrichment .

4.1 SCALE 123-group validation results for highly enriched uranium cascs 


\section{LIST OF TABLES}

Table

$\underline{\text { Page }}$

2.1 CSAS25/KENO-V.a results with the 123-group cross-section library for a set of low-enriched

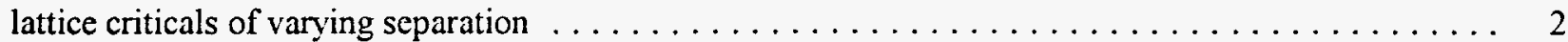

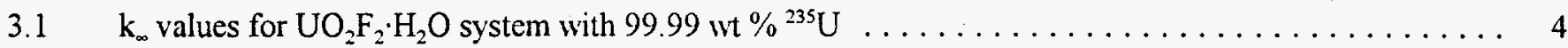

$3.2 \quad \mathrm{k}_{\infty}$ values for $\mathrm{UO}_{2} \mathrm{~F}_{2} \cdot \mathrm{H}_{2} \mathrm{O}$ system with 5.0 wt $\%{ }^{235} \mathrm{U} \ldots \ldots \ldots \ldots \ldots \ldots \ldots \ldots \ldots$

3.3 $\mathrm{k}_{\infty}$ values for $\mathrm{UO}_{2} \mathrm{~F}_{2} \cdot \mathrm{H}_{2} \mathrm{O}$ highly enriched uranium system using revised 123 -group library $\ldots \ldots \ldots$

4.1 Values of $k_{\text {eff }}$ for the NRC model of the highly enriched package array $\ldots \ldots \ldots \ldots \ldots \ldots \ldots$

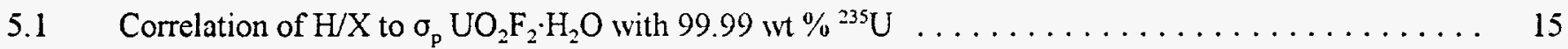





\section{ACKNOWLEDGMENTS}

The authors are grateful for the consultation of L. M. Petrie and R. M. Westfall, who assisted in identification of data characteristics that could impact the adequacy of the 123-group library. S. M. Bowman's work to analyze selected critical experiments for trends with separation distance is also appreciated. This work was performed under the direction of M. G. Bailey of the Office of Nuclear Matcrial Safety and Safeguards of the U.S. Nuclear Regulatory Commission. 


\section{BACKGROUND}

The 123-group neutron cross-section library ${ }^{1}$ has been included within the SCALE code system ${ }^{2}$ since the initial release of the system in 1980. The library originates from pre-ENDF (Evaluated Nuclear Data Files) data as provided with the GAM- $\mathrm{II}^{3}$ and THERMOS ${ }^{4}$ codes. The group structure is a combination of the 99 groups ( 93 fast groups) used by GAM and the 30 thermal groups (below $1.86 \mathrm{cV}$ ) used by THERMOS. The library was created circa 1970 at the request of the now-defunct Reactor Division at Oak Ridge National Laboratory (ORNL) for use in the analysis of water-moderated reactor lattices. In the early 1970s when ORNL began supporting the cask certification staff at the U.S. Atomic Energy Commission (AEC), the 16-group Hansen-Roach library (originally developed for the analysis of fast systems) and the 123-group library were the only multigroup libraries that were both readily available and accepted for criticality safety analyses. At the request of the certification staff, ORNL processed ENDF/B-IV data to provide a few additional lightelement nuclides to the 123-group library (e.g., calcium for use in concrete mixtures) and included the library in the data base for the SCALE code system.

Development of the 27-group library ${ }^{1}$ based on ENDF/B-IV data was completed by ORNL in the late $1970 \mathrm{~s}$ and was also included in the initial release of the SCALE code system. Although seldom used at ORNL after 1980, the 123-group library had become accepted by industry because of its solid performance in the analysis of thermal criticality systems ${ }^{5-7}$ and the large number of nuclides available in the library. Reduced use at ORNL was based on the age and pedigree of the cross-section data, not because of any specific indication of poor results against measured data. In the early 1990 s ORNL processed a 238group ${ }^{8}$ library from ENDF/B-V data and used a lightwater-reactor (LWR) fuel pin flux to collapse the 238group data into a 44-group library. ${ }^{9}$

In the fall of 1994, the cask certification staff at the U.S. Nuclear Regulatory Commission (NRC) performed a series of analyses on an array of optimally moderated packages containing highly enriched ${ }^{235} \mathrm{U}$. The analyses showed that the 123-group library gave $k_{\text {eff }}$ results that were 3 to $3.5 \%$ lower than results obtained both with the 27 -group library and the recently developed 44-group library. The analyses were all performed with SCALE-4.2 using the CSAS25/KENO-V.a sequence. Independent analyses using the MONK code and data ${ }^{10}$ were performed by certification staff in the United Kingdom and indicated similar results to those obtained by the NRC staff with the 27- and 44-group libraries. Because the package safety analysis had been performed with the 123group data, the NRC staff requested that ORNL investigate this discrepancy (1) to determine the reason for the discrepancy and (2) to provide guidance on the type(s) of systems where the discrepancy could result in a safety concern. The next three sections review the work in chronological order, and the last section provides a summary of the findings and recommendations for consideration by the NRC staff and the user community. 


\section{INITIAL SCOPING EFFORTS}

After being notified of the analytical discrepancies by the NRC staff, the initial assumption by the ORNL staff was that there was a deficiency in the hydrogenscattering cross section that yielded discrepancies in calculated $k_{\text {eff }}$ values for systems with a large number of mean-free paths between fissile units. Thus the staff began a search for measured critical systems that would enable this assumption to be tested. A set of highly enriched criticals that appeared to have the requisite separation between units were located, but calculational models for the systems were not readily available. Therefore a set of readily available, lowenriched critical arrays with varying unit separation distances were analyzed using models developed as part of the validation effort of the 44-group library. ${ }^{9}$ As the results in Table 2.1 demonstrate, these analyses show no consistent trend with separation distance and indicate generally good agreement with the measured condition.

The results obtained by the NRC staff, as well as the validation used by the licensee, were reviewed at ORNL. The criticals used by the licensee appeared sufficient to validate the presence of interstitial moderator between array units, and the validation results had acceptable agreement with measured results. This situation, together with the ORNL results to investigate the effect of unit separation, indicated that the discrepancy resulted more from the particle interaction physics within the fissile material than from the radiation transport between units. It was determined that a simple system should be used to help isolate the cause of the discrepancy and help characterize systems where the discrepancy would appear.
Table 2.1 CSAS25/KENO-V.a results with the 123-group cross-section library for a set of lowenriched lattice criticals of varying separation

\begin{tabular}{|c|c|c|}
\hline $\begin{array}{c}\text { Case } \\
\text { identifier }\end{array}$ & $\begin{array}{c}\mathbf{k}_{\text {eff }} \\
\text { value }\end{array}$ & $\begin{array}{c}\begin{array}{c}\text { Unit } \\
\text { separation } \\
(\mathrm{cm})\end{array} \\
\end{array}$ \\
\hline baw1484a & $0.9986(0.0010)$ & 1.636 \\
\hline baw1484b & $0.9830(0.0013)$ & 6.544 \\
\hline baw1484c & $1.0003(0.0014)$ & 1.636 \\
\hline baw1484d & $0.9815(0.0014)$ & 1.636 \\
\hline p2438x05 & $0.9981(0.0014)$ & 8.39 \\
\hline p $2438 \times 17$ & $0.9979(0.0010)$ & 5.05 \\
\hline p $2438 \times 28$ & $0.9996(0.0014)$ & 6.88 \\
\hline p2615x14 & $0.9920(0.0014)$ & 8.58 \\
\hline p2615x31 & $0.9956(0.0015)$ & 6.72 \\
\hline p282712a & $0.9997(0.0014)$ & 13.72 \\
\hline p282712b & $1.0022(0.0008)$ & 20.78 \\
\hline p2827non & $0.9964(0.0014)$ & 8.31 \\
\hline p2827u2a & $0.9990(0.0013)$ & 14.11 \\
\hline p2827u2b & $0.9956(0.0014)$ & 15.32 \\
\hline p3314a & $0.9997(0.0016)$ & $2.83 / 3.60$ \\
\hline p3314b & $1.0026(0.0011)$ & $2.83 / 4.94$ \\
\hline p3602b4 & $0.9968(0.0015)$ & 8.30 \\
\hline p3602n2 & $1.0026(0.0013)$ & 11.20 \\
\hline p3602non & $0.9996(0.0017)$ & 15.84 \\
\hline p3602s4 & $0.9980(0.0015)$ & 9.83 \\
\hline p392612a & $0.9929(0.0015)$ & 10.11 \\
\hline p392614a & $0.9967(0.0016)$ & 18.18 \\
\hline p3926n2 & $0.9930(0.0015)$ & 6.59 \\
\hline p3926nob & $0.9903(0.0016)$ & 12.91 \\
\hline p3926u2a & $0.9974(0.0013)$ & 9.50 \\
\hline p3926u4a & $0.9943(0.0015)$ & 19.24 \\
\hline
\end{tabular}

${ }^{3}$ The case identifier is the same as used in Ref. 4. 


\section{IDENTIFICATION OF THE PROBLEM}

The NRC model of the packaging system was used to define a simple, yet representative, system. An infinite system of $\mathrm{UO}_{2} \mathrm{~F}_{2} \cdot \mathrm{H}_{2} \mathrm{O}$ was selected for study because of its simplicity and the significant amount of knowledge available on its neutronic behavior (a number of $\mathrm{UO}_{2} \mathrm{~F}_{2} \cdot \mathrm{H}_{2} \mathrm{O}$ critical systems have been analyzed and used in parameter studies ${ }^{10}$ ). The oxygen and fluorine are scattering materials that provide little thermalization and very small capture cross sections. Thus this system has the essential neutronic elements of a flooded fissile uranium package without the complexity of an actual package. The approach was to analyze the system using both the 123-group library and the new ENDF/B-V libraries for a range of hydrogen-to-fissile material ratios $(\mathrm{H} / \mathrm{X})$ and for ${ }^{235} \mathrm{U}$ enrichment values of $99.99 \mathrm{wt} \%$ and $5.0 \mathrm{wt} \%$. The variation in $\mathrm{H} / \mathrm{X}$ values provided a change in the system spectrum from thermal $(H / X>200)$ to fast $(H / X<10)$, whereas the enrichment variation was needed to assess whether the discrepancy even occurred for low-enriched systems. The $k_{\infty}$ values calculated for the $\mathrm{UO}_{2} \mathrm{~F}_{2} \cdot \mathrm{H}_{2} \mathrm{O}$ systems using the CSAS1/XSDRNPM sequence of SCALE are provided in Tables 3.1 and 3.2.

The results for the highly enriched cases in Table 3.1 indicate that for well-thermalized systems $(\mathrm{H} / \mathrm{X}>200)$ the SCALE 123-group library yields $k_{\infty}$ values that are approximately $0.5 \%$ lower than values obtained with both the ENDF/B-V libraries. However, as H/X decreases and the spectrum hardens, the difference in $\mathrm{k}_{\infty}$ results between the 123-group library and the ENDF/B-V libraries increases. A discrepancy between 5.5 and $6 \%$ is observed for $\mathrm{H} / \mathrm{X}$ values in the range of 5 to 10 . The highly enriched uranium package modeled by the NRC had an $\mathrm{H} / \mathrm{X}$ value of 21 . At this $\mathrm{H} / \mathrm{X}$ value the results of Table 3.1 show a $4 \%$ discrepancy, which is of the same magnitude seen by the NRC with the actual package system.

For the low-enriched system, the results of Table 3.2 indicate that the 238- and 123-group results generally agree to within about $0.5 \%$ for all but the very lowest $\mathrm{H} / \mathrm{X}$ values. However, comparison of the 44 - and 123-group results seems to indicate a discrepancy similar to that observed for the highly enriched system, but with a maximum difference of only $2 \%$. Since the 238-group library is the parent fine-group library for the 44-group data, any bias in the 123-group library is more accurately defined by comparison with the 238group results. Thus the ORNL staff concludes that the discrepancy between the 123-group and 44-group results in the low $\mathrm{H} / \mathrm{X}$ range is due to the fact that the 44-group library was collapsed from the 238-group library using a thermal flux representative of a LWR fuel pin. This collapsing flux is not representative of the $\mathrm{UO}_{2} \mathrm{~F}_{2} \cdot \mathrm{H}_{2} \mathrm{O}$ systems with low $\mathrm{H} / \mathrm{X}$ values and can lead to inaccurate treatment of the ${ }^{238} \mathrm{U}$ resonances. Thus for these hard-spectra, low-enriched systems where the effects of ${ }^{238} \mathrm{U}$ resonances dominate, the 44group library appears to have a bias that increases with decreasing $\mathrm{H} / \mathrm{X}$.

A summary of the 44- and 123-group results provided in Tables 3.1 and 3.2 are shown in Figure 3.1, where the $k_{\infty}$ values are plotted as a function of the average energy causing fission (AEF). Figure 3.1 shows that for the highly enriched systems the AEF obtained in the 123-group calculations is slightly higher than that obtained with the 44-group library, whereas for the low-enriched systems, the AEF is the same or slightly lower than that obtained with the 44-group library. The conclusions drawn from Figure 3.1 and the data of Tables 3.1 and 3.2 are that the discrepancy of concern with the 123-group library (1) is significant for highly enriched systems with $\mathrm{H} / \mathrm{X}<100$, and (2) appears to result from a problem with the ${ }^{235} \mathrm{U}$ cross-section data because the discrepancy is only apparent for highly enriched systems.

To help confirm the proposed cause for the discrepancy in $k_{\infty}$, the ${ }^{235} \mathrm{U}$ fission cross sections in each ENDF/B-V library were compared with the 123group library, as shown in the plots of Figures 3.2 and 3.3. Although the energy group boundaries are not identical, it is obvious that the 123-group cross sections are generally higher in the resonance energy range between 1 and $100 \mathrm{eV}$. The higher ${ }^{235} \mathrm{U}$ absorption that results from these higher cross sections causes the flux below the resonance range to be too low (see Figure 3.4). The low flux reduces the number of fissions (see Figure 3.5) and provides an underprediction of $k_{\infty}$ for the cases with $\mathrm{H} / \mathrm{X}<100$. 
Table $3.1 \mathrm{k}_{\mathrm{o}}$ values for $\mathrm{UO}_{2} \mathrm{~F}_{2} \cdot \mathrm{H}_{2} \mathrm{O}$ system with $99.99 \mathrm{wt} \%{ }^{235} \mathrm{U}$

\begin{tabular}{|c|c|c|c|c|c|}
\hline $\mathbf{H} / \mathbf{X}$ & $\begin{array}{c}\text { 123-group } \\
k_{\infty}\end{array}$ & $\begin{array}{c}\text { 44-group } \\
k_{\infty}\end{array}$ & $\frac{k_{123}-k_{44}}{k_{44}}, \%$ & $\begin{array}{c}238-\text { group } \\
\mathbf{k}_{\infty}\end{array}$ & $\frac{k_{123}-k_{238}}{k_{238}}, \%$ \\
\hline 0 & 2.0443 & 2.0756 & -1.51 & 2.0852 & -1.98 \\
\hline 5 & 1.7046 & 1.8080 & -5.72 & 1.8038 & -5.50 \\
\hline 10 & 1.7035 & 1.8086 & -5.81 & 1.8034 & -5.54 \\
\hline 20 & 1.7672 & 1.8436 & -4.14 & 1.8399 & -3.95 \\
\hline 50 & 1.8608 & 1.8951 & -1.81 & 1.8939 & -1.75 \\
\hline 100 & 1.8815 & 1.8987 & -0.91 & 1.8984 & -0.89 \\
\hline 200 & 1.8341 & 1.8441 & -0.54 & 1.8441 & -0.54 \\
\hline 300 & 1.7676 & 1.7758 & -0.46 & 1.7759 & -0.46 \\
\hline 500 & 1.6362 & 1.6432 & -0.43 & 1.6435 & -0.44 \\
\hline 700 & 1.5188 & 1.5256 & -0.45 & 1.5259 & -0.47 \\
\hline
\end{tabular}

Table $3.2 \mathrm{k}_{\infty}$ values for $\mathrm{UO}_{2} \mathrm{~F}_{2} \cdot \mathrm{H}_{2} \mathrm{O}$ system with $5.0 \mathrm{wt} \%{ }^{235} \mathrm{U}$

\begin{tabular}{|c|c|c|c|c|c|}
\hline $\mathbf{H} / \mathbf{X}$ & $\begin{array}{c}\text { 123-group } \\
k_{\infty}\end{array}$ & $\begin{array}{c}\text { 44-group } \\
k_{\infty}\end{array}$ & $\frac{k_{123}-k_{44}}{k_{44}}, \%$ & $\begin{array}{c}\text { 238-group } \\
k_{\infty}\end{array}$ & $\frac{k_{123}-k_{238}}{k_{238}}, \%$ \\
\hline 5 & 0.9074 & 0.9133 & -0.65 & 0.8964 & 1.22 \\
\hline 10 & 0.9734 & 0.9916 & -1.84 & 0.9736 & -0.02 \\
\hline 20 & 1.0843 & 1.1070 & -2.05 & 1.0909 & -0.61 \\
\hline 50 & 1.2722 & 1.2885 & -1.27 & 1.2792 & -0.55 \\
\hline 100 & 1.3921 & 1.4026 & -0.75 & 1.3979 & -0.41 \\
\hline 200 & 1.4499 & 1.4575 & -0.52 & 1.4557 & -0.40 \\
\hline 300 & 1.4435 & 1.4504 & -0.48 & 1.4497 & -0.43 \\
\hline 500 & 1.3847 & 1.3913 & -0.47 & 1.3914 & -0.48 \\
\hline 700 & 1.3128 & 1.3192 & -0.49 & 1.3196 & -0.52 \\
\hline 1000 & 1.2084 & 1.2146 & -0.51 & 1.2152 & -0.56 \\
\hline 1500 & 1.0600 & 1.0659 & -0.55 & 1.0666 & -0.62 \\
\hline 2000 & 0.9415 & 0.9471 & -0.59 & 0.9477 & -0.59 \\
\hline
\end{tabular}




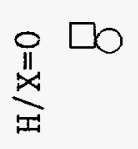
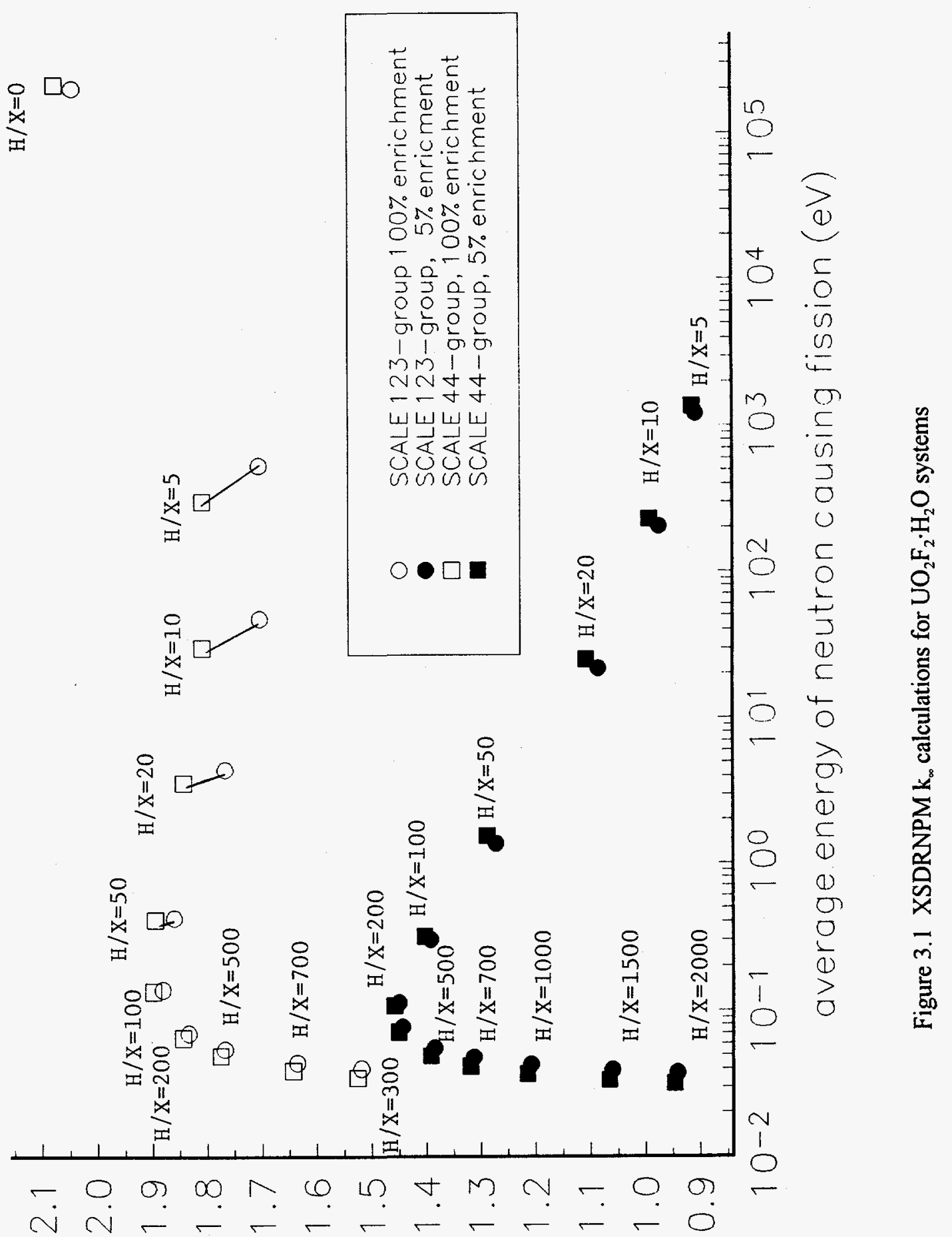

$$
\text { Kł! !! !u!-y }
$$




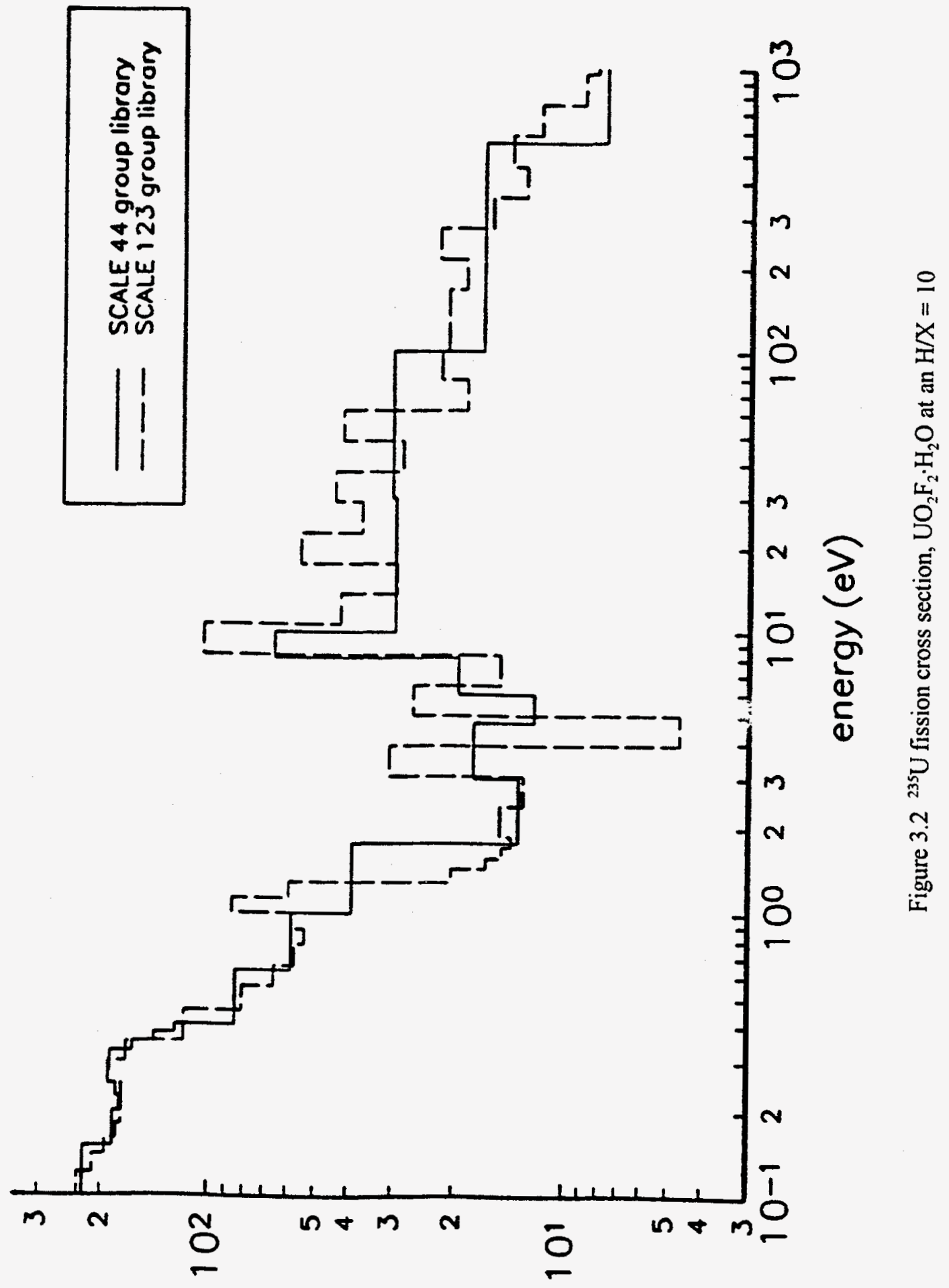

(sujoq) Uo!f oas ssojo vo!ss! 


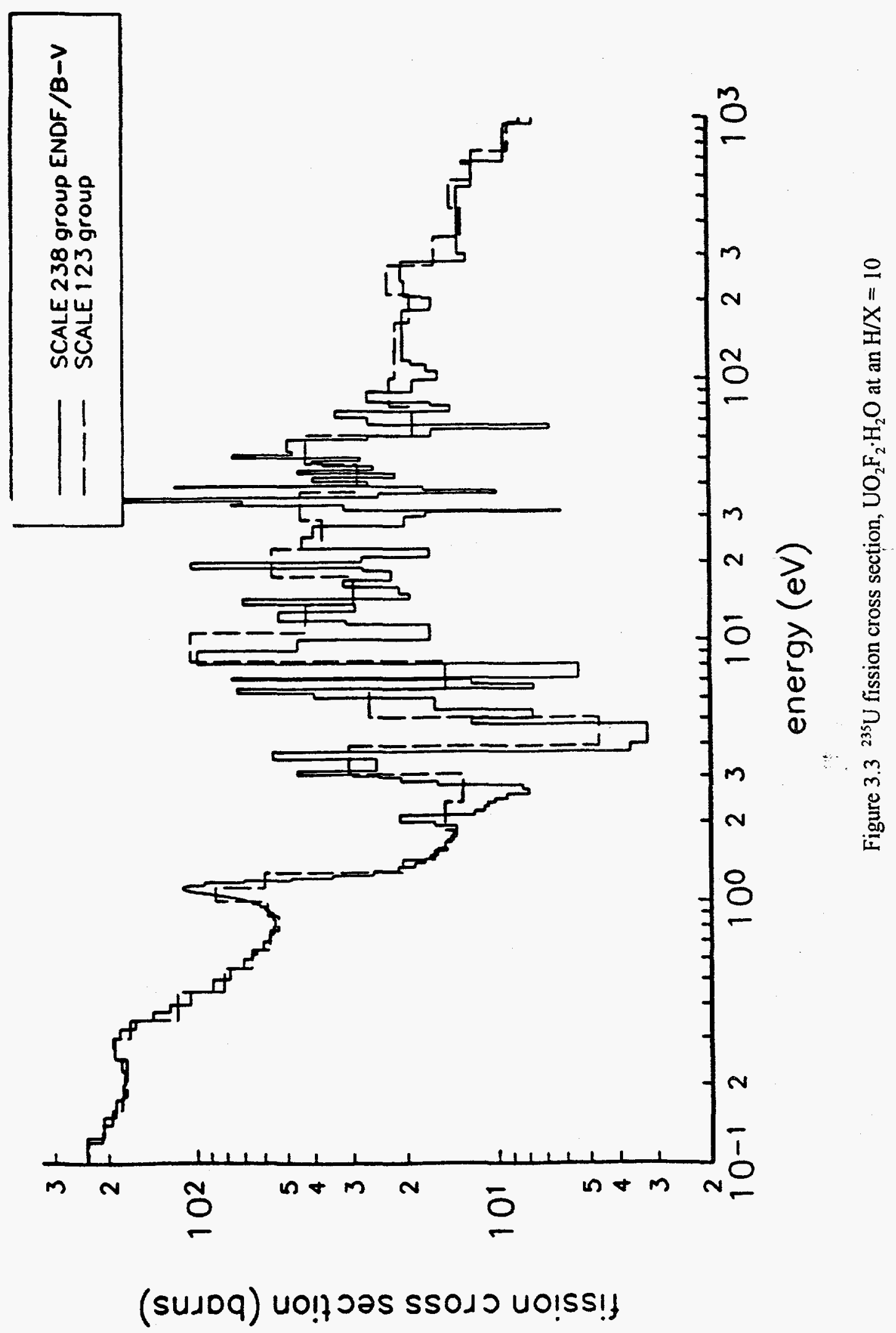




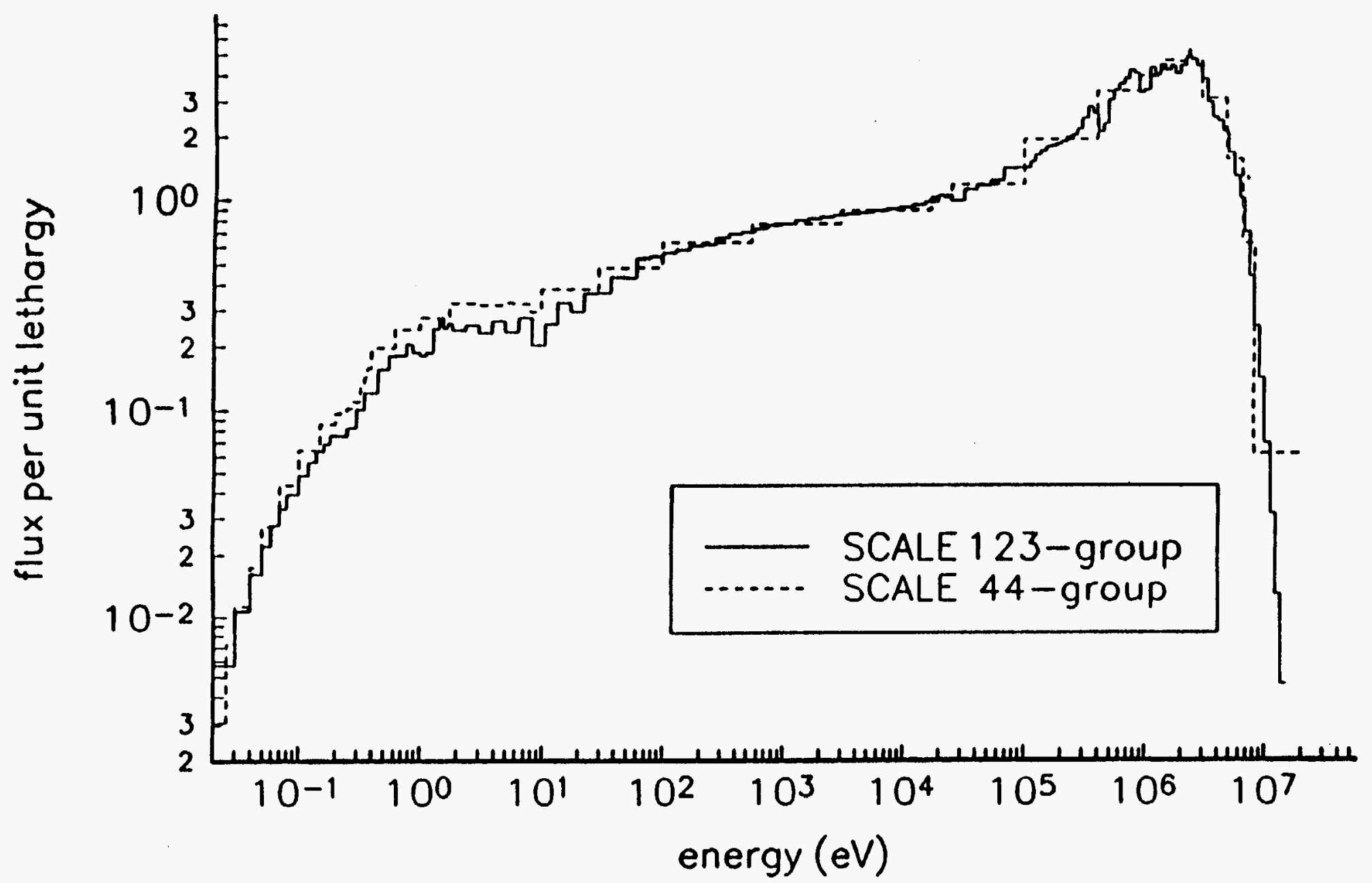

Figure 3.4 Flux using group data for highly enriched $\mathrm{UO}_{2} \mathrm{~F}_{2} \cdot \mathrm{H}_{2} \mathrm{O}$ systems at an $\mathrm{H} / \mathrm{X}=10$ 


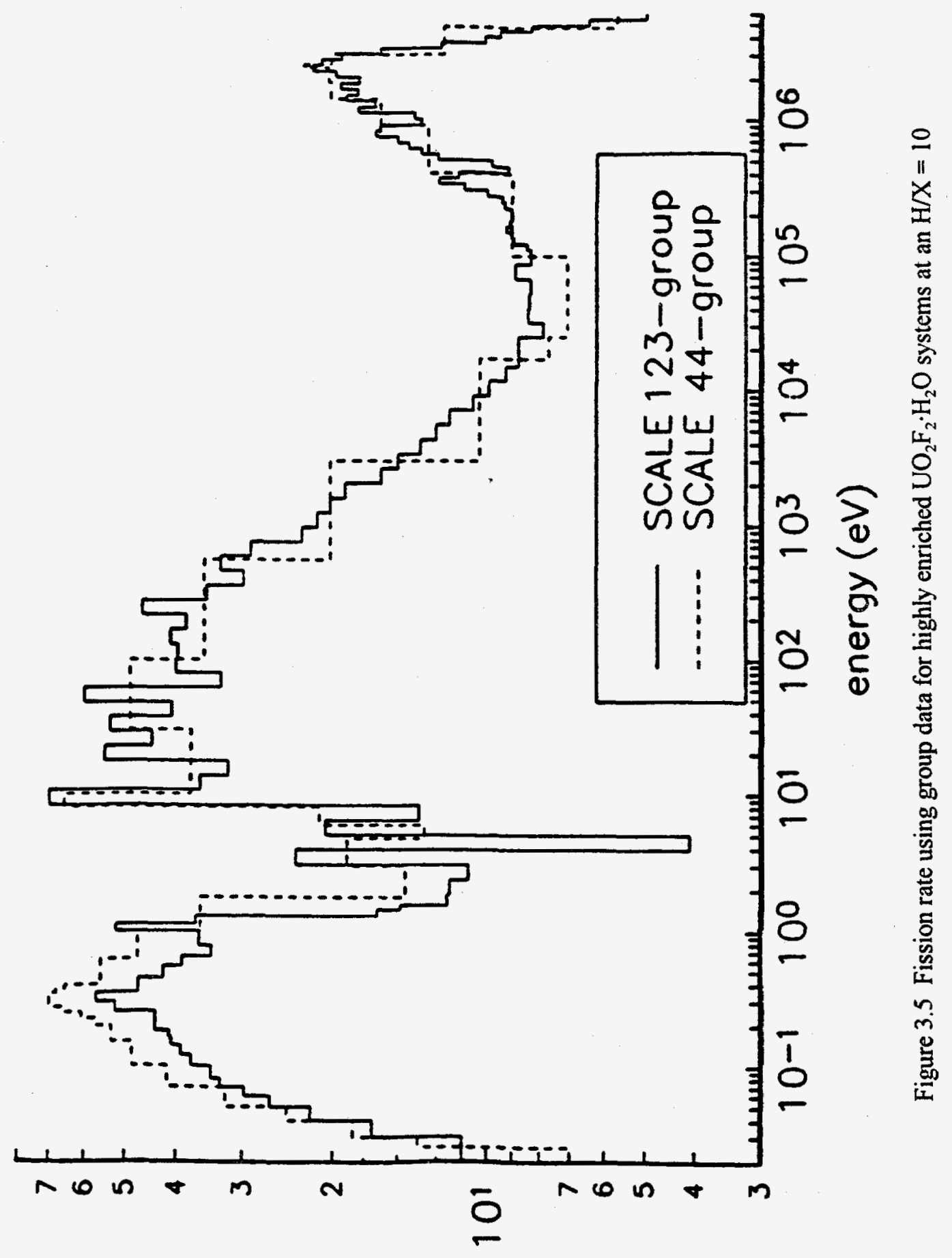

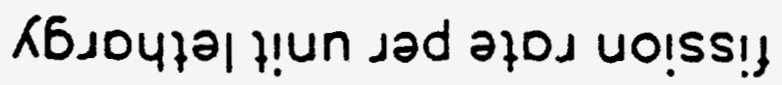


The reason for the high cross sections in the resonance region can be traced back to a lack of resonance parameters for ${ }^{235} \mathrm{U}$ in the 123-group library. The ${ }^{235} \mathrm{U}$ data were preshielded for LWR applications or correspond to nearly infinite dilution (i.e., $\mathrm{H} / \mathrm{X}=\infty$ ). Thus the same ${ }^{235} U$ cross sections are used for all cases. This methodology is incorrect in general, but is especially bad for the highly enriched cases with low $\mathrm{H} / \mathrm{X}$ values. Figure 3.6 shows a modification of Figure 3.1 with additional data provided for the highly enriched cases using the 44-group library with ${ }^{235} U$ processed at $\mathrm{H} / \mathrm{X}=0$ and $\mathrm{H} / \mathrm{X}=\infty$. Note that using a fixed value of $\mathrm{H} / \mathrm{X}=\infty$ for ${ }^{235} \mathrm{U}$ resonance processing in the 44-group library causes the 44- and 123-group results to be in much better agreement for the low $\mathrm{H} / \mathrm{X}$ cases.

A final confirmation of the cause of the discrepancy was obtained by generating a new set of ${ }^{235} U$ crosssection data for the 123-group library. The data were generated from ENDF/B-V data into the 123-group energy structure using the AMPX-77 code system. The $k_{\infty}$ values shown in Table 3.3 indicate that the revised 123-group library provides excellent agreement with the 238-group library for all the highly enriched $\mathrm{UO}_{2} \mathrm{~F}_{2} \cdot \mathrm{H}_{2} \mathrm{O}$ systems.

Table $3.3 \mathrm{k}_{\infty}$ values for $\mathrm{UO}_{2} \mathrm{~F}_{2} \cdot \mathrm{H}_{2} \mathrm{O}$ highly enriched uranium system using revised 123-group library

\begin{tabular}{rcc}
\hline Revised & $\begin{array}{c}\text { Red } \\
\text { 123-group } \\
\mathbf{k}_{\infty}\end{array}$ & $\begin{array}{c}\text { 238-group } \\
\mathbf{k}_{\infty}\end{array}$ \\
\hline 0 & 2.0852 & 2.0852 \\
5 & 1.7969 & 1.8038 \\
10 & 1.8022 & 1.8034 \\
20 & 1.8415 & 1.8399 \\
50 & 1.8963 & 1.8939 \\
100 & 1.9006 & 1.8984 \\
200 & 1.8458 & 1.8441 \\
300 & 1.7771 & 1.7759 \\
500 & 1.6439 & 1.6435 \\
700 & 1.5258 & 1.5259 \\
\hline
\end{tabular}

The last columns of Tables 3.1 and 3.2 also indicate that results with the 123-group library increase relative to results with the 238-group library for systems with very low $\mathrm{H} / \mathrm{X}$. This trend explains why the 123-group library has performed reasonably well in calculating fast criticals and thermal criticals even though a significant bias appears to exist between these extremes. The cause for this discrepancy at very low $\mathrm{H} / \mathrm{X}$ values appears to be differences in the ${ }^{235} \mathrm{U}$ cross-section data at high energies. The high energy of these very low $\mathrm{H} / \mathrm{X}$ systems is far beyond the current area of concern, and a detailed investigation of the differences in data was not performed. However, the excellent agreement shown in Table 3.3 with the modified 123-group ${ }^{235} \mathrm{U}$ data confirms that the cause of the discrepancy in $\mathrm{k}_{\infty}$ is due to differences in ${ }^{235} \mathrm{U}$ data. 


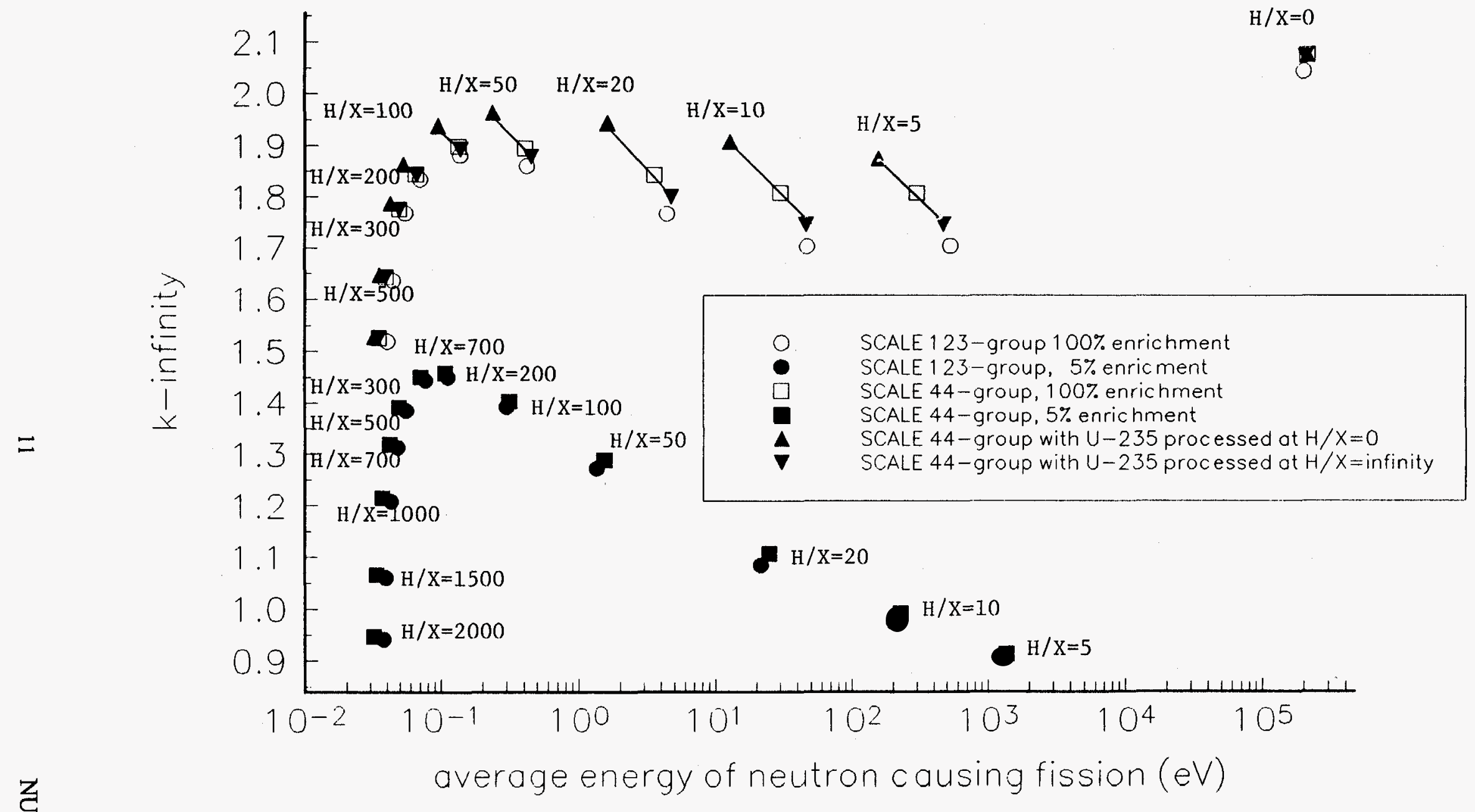

Figure 3.6 XSDRNPM $\mathrm{k}_{\infty}$ calculations for $\mathrm{UO}_{2} \mathrm{~F}_{2} \cdot \mathrm{H}_{2} \mathrm{O}$ systems, $100 \%$ and $5 \%$ enrichment 


\section{APPLICATION TO REAL SYSTEMS}

The revised 123-group library was used to analyze the NRC model of the packaging system where the discrepancy was originally observed. The $k_{\mathrm{ef}}$ results obtained with the revised 123-group library, the standard 123-group library, the 27-group library, and the 238-group library are shown in Table 4.1. All the analyses were performed with the CSAS25/KENO-V sequence of SCALE. Table 4.1 also shows the $k_{\text {eff }}$ values obtained using the $P_{0}$ scattering approximation. Note that although the calculated $k_{\text {eff }}$ values change significantly from $P_{3}$ to $P_{0}$, the discrepancy between the libraries does not change which reinforces the conclusion that hydrogen scattering does not play a significant role in the discrepancy under investigation.

As indicated early in this report, ORNL had shown in the late 1970s that the 123-group library agreed well with measured low-enriched uranium criticals. Figure 7 in ref. 12 shows the results of CSAS25/KENO-V calculations performed on a set of highly enriched criticals. Four of the criticals used by the licensee for analysis validation of the packaging system under study are included in Figure 7 and are designated as "J. T. Thomas metal cylinder arrays." Note that these criticals have an AEF that is several orders of magnitude higher than that obtained with the NRC model of the packaging system under study. Also, one can observe that there is a broad range of AEF not covered by these criticals or any other criticals that are readily known to the ORNL staff. Adding to this lack of data is the apparent trend for $k_{\text {eff }}(1)$ to decrease with increasing AEF based on the thermal system data and (2) to decrease with decreasing AEF based on the fast system data. This bias trend is also seen in the plot of the bias between the 123-group and 44group libraries for the $\mathrm{UO}_{2} \mathrm{~F}_{2} \cdot \mathrm{H}_{2} \mathrm{O}$ system discussed above. This anomalous trend is caused by the fact that the ${ }^{235} \mathrm{U}$ data for the standard 123-group library is preshielded to a fixed value. This fixed resonance selfshielded value is adequate for thermal systems and has little or no consequence for fast systems; however, in the intermediate range an accurate self-shielded value is important, and the preshielded value is inadequate.

Table 4.1 Values of $k_{\text {eff }}$ for the NRC model of the highly enriched package array

Model identifier

Library

ann 6ao

ann 7ao

27-group

$\mathbf{P}_{0}$ scatter

$1.1303(0.0036)$

$1.1291(0.0038)$

$\mathbf{P}_{3}$ scatter

$0.9628(0.0036)$

$0.9550(0.0039)$

123-group

$P_{0}$ scatter

$1.0878(0.0036)$

$1.0817(0.0036)$

$\mathbf{P}_{3}$ scatter

$0.9316(0.0039)$

$0.9194(0.0035)$

Revised 123-group

$P_{0}$ scatter

$P_{3}$ scatter

238-group

$\mathbf{P}_{3}$ scatter
$1.1180(0.0041)$

$0.9558(0.0037)$

$1.1245(0.0040)$

$0.9485(0.0035)$

$0.9539(0.0036)$ 


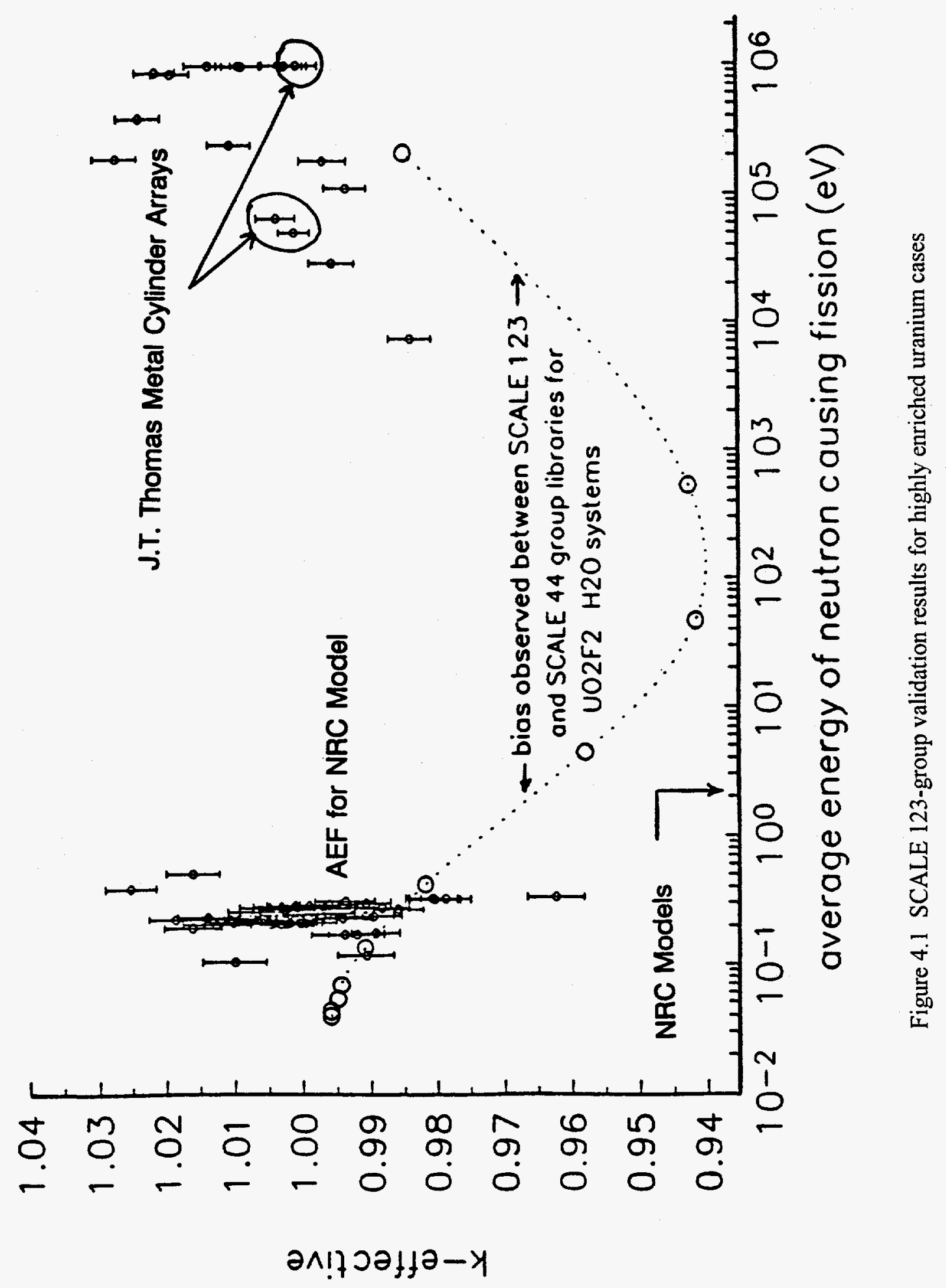




\section{CONCLUSIONS AND RECOMMENDATIONS}

The SCALE 123-group library does not contain resonance data for ${ }^{235} \mathrm{U}$. A fixed resonance selfshielding value, corresponding apparently to an infinite dilute system, is provided by the original GAM-THERMOS data. This situation can cause unacceptable, nonconservative discrepancies between $k_{\text {eff }}$ values calculated with the 123-group library and libraries that provide for a more rigorous treatment of the resonance region. Based on this study, the nonconservative bias is insignificant in low-enriched systems but can be as large as $5.5 \%$ for highly enriched systems with intermediate AEF values between thermal and fast.

In general situations where the AEF has not been calculated, it is recommended that the $\sigma_{p}$ value for ${ }^{235} \mathrm{U}$ be examined to determine if the calculation might have been influenced by the ${ }^{235} \mathrm{U}$ cross-section deficiency in the 123-group library. The $\sigma_{p}$ value for nuclide $j$ may be estimated by

$$
\sigma_{p j}=\left[\sum_{\substack{i \\ i \times j}} N_{i} \sigma_{s i}+\frac{1.0-C}{\bar{l}}\right] / N_{j}
$$

where

$$
\begin{aligned}
& \sigma_{\mathrm{si}} \quad=\text { effective scatter cross section of admixed } \\
& \mathrm{N}_{\mathrm{i}} \quad=\text { number density of admixed nuclide } i \\
& \frac{1.0-\mathrm{C}}{\bar{l}}=\underset{\text { represents the effects of external }}{\text { moderators }} \\
& \text { where } \\
& \text { C } \equiv \text { Dancoff factor and } \\
& \bar{l} \quad \equiv \text { mean chord length for the fuel lump } \\
& {[=(4 * \text { volume of lump }) / \text { (surface area of }} \\
& \text { lump)] }
\end{aligned}
$$

Although the $H / X$ value is a good initial indicator of the thermalization of a system, the $\sigma_{\mathrm{p}}$ value is better for general characterization purposes because it allows consideration of the effects of nonhydrogen moderators and/or external moderators. Table 5.1 gives the correlation of $\mathrm{H} / \mathrm{X}$ to $\sigma_{\mathrm{p}}$ for the high enrichment $\mathrm{UO}_{2} \mathrm{~F}_{2} \cdot \mathrm{H}_{2} \mathrm{O}$ cases of Table 3.2. Any 123group calculation of a highly enriched uranium system could have a significant nonconservative bias if the ${ }^{235} \mathrm{U} \sigma_{p}$ value is in the range of approximately 15 to 2000 .

Unfortunately, there is no means to validate any library for systems where the intermediate-energy range is significant because there is an almost nonexistent data base of pertinent measured criticals. For real systems in this region the practitioner is left with little choice but to rely on corroborative agreement between independent analyses with various cross-section libraries and data processing schemes, together with development of trends with AEF indicated by available criticals in order to develop an appropriate calculational bias. Work to develop guidelines for defining the range beyond which validation trends should not be extended has been proposed. The DOE also has intermediate-energy criticals listed as a high priority for future experimental programs. Acquisition of intermediate-energy critical data from the countries of the former Soviet Union is also a possibility.

In summary, the ORNL staff recommends that the 123-group library not be used for analysis of highly enriched systems because of the deficiency of the ${ }^{235} U$ data. In fact, any calculations performed with the 123group library should be considered biased until demonstrated otherwise. Careful consideration should be given to the range of validation and applicability of the validation to the systems at hand. Libraries such as the recently developed 44-group and 238-group libraries enable rigorous treatment of the well-tested ENDF/B-V data and should be better libraries (validation by the user is still required) for use with highly enriched systems. Similarly, the SCALE 27 group library has been demonstrated to perform well for highly enriched systems. For systems with an AEF outside the range of available critical data, independent analyses with other codes and data should be investigated and trends in $k_{\text {eff }}$ as a function of AEF should be carefully studied. 
Table 5.1 Correlation of $\mathrm{H} / \mathrm{X}$ to $\sigma_{p} \mathrm{UO}_{2} \mathrm{~F}_{2} \cdot \mathrm{H}_{2} \mathrm{O}$ with 99.99 wt $\%{ }^{235} \mathrm{U}$

\begin{tabular}{|c|c|c|}
\hline$\underline{H} / \mathbf{X}$ & $\underline{\sigma}_{p}{ }^{2}$ & Bias, $_{3}^{b} \%$ \\
\hline 0 & 15 & -1.98 \\
\hline 5 & 124 & -5.50 \\
\hline 10 & 233 & -5.54 \\
\hline 20 & 452 & -3.95 \\
\hline 50 & 1,107 & -1.75 \\
\hline 100 & 2,200 & -0.89 \\
\hline 200 & 4,385 & -0.54 \\
\hline 300 & 6,570 & -0.46 \\
\hline 500 & 10,940 & -0.44 \\
\hline 700 & 15,310 & -0.46 \\
\hline
\end{tabular}


67. C. Haught, Martin Marietta Utilities Services, P.O. Box 628, MS 5023, Piketon, OH 45661

68. L. Hassler, Babcock \& Wilcox, P.O. Box 10935, Lynchburg, VA 24506-0935

69. T. Jones, U.S. Nuclear Regulatory Commission, Divisoin of Fuel Cycle Safety and Safeguards, MS TA D-14, Washington, DC 20555

70. M. Klasky, U.S. Nuclear Regulatory Commission, Division of Fuel Cycle Safety and Safeguards, Licensing Branch, MS TA D-14, Washington, DC 20555

71. R. Lemming, Martin Marietta Utilities Services, P.O. Box 628, MS 5023, Piketon, OH 45661

72. L. Lessler, U.S. Nuclear Regulatory Commission, Divisoin of Fuel Cycle Safety and Safeguards, MS TA D-14, Washington, DC 20555

73. H. Lutz, Lawrence Livermore National Laboratory, P.O. Box 808, L-634, Livermore, CA 94551

74. H. Manaktala, Center for Nuclear Waste Regulatory Analyses, Southwest Research Institute, 6220 Culebra Road, San Antonio, TX 78238-5166

75. C. Marotta, 1504 Columbia Ave., Rockville, MD 20850

76. M. Mason, Transnuclear, Two Skyline Drive, Hawthorne, NY 10532-2120

77. D. Napolitano, Nuclear Assurance Corp., 5720 Peachtree Parkway, Norcross, GA 30092

78. C. W. Nilsen, Office of Nuclear Material Safety and Safeguards, U.S. Nuclear Regulatory Commission, MS TWFN-9F29, Washington, DC 20555

79-80. Office of Scientific and Technical Information, U.S. Department of Energy, P.O. Box 62, Oak Ridge, TN 378312

81. Office of the Assistant Manager for Energy Research and Development, Department of Energy Oak Ridge Operations (DOE-ORO), P.O. Box 2008, Oak Ridge, TN 37831

82. N. Osgood, U.S. Nuclear Regulatory Commission, Office of Nuclear Materials Safety and Safeguards, TWFN 8F5, Washington, DC 20555

83. R. Oxenham, Martin Marietta Utilities Services, P.O. Box 628, MS 5023, Piketon, OH 45661

84. P. Pacquin, General Nuclear Systems, Inc., 220 Stoneridge Dr., Columbia, SC 29210

85. F. C. Sturz, Office of Nuclear Material Safety \& Safeguards, U.S. Nuclear Regulatory Commission, MS TWFN 8F5, Washington, DC 20555

86. R. Tayloe, Battelle, 505 King Avenue, Room 11-10-070, Columbus, $\mathrm{OH} 43201$

87. T. Taylor, INEL, P.O. Box 4000, MS 3428, Idaho Falls, ID 83403

88. B. Thomas, VECTRA Technologies, Inc., 6203 San Ignacio Ave., Suite 100, San Jose, CA 95119

89. J. R. Thornton, TRW Environmental Safety Systems, 2650 Park Tower Dr., Suite 800, Vienna, VA 22180

90. H. Toffer, Westinghouse Hanford Co., P.O. Box 1970, Richland, WA 99352

91. G. Walden, Duke Power Co., P.O. Box 33189, Charlotte, NC 28242

92. M. E. Wangler, U.S. Department of Energy, EH-33.2, Washington, DC 20585-0002

93. R. Weller, U. S. Nuclear Regulatory Commission, TWFN 7J9, Washington, DC 20555

94. A. Wells, 2846 Peachtree Walk, Duluth, GA 30136

95. B. H. White, Office of Nuclear Material Safety \& Safeguards, U.S. Nuclear Regulatory Commission, MS TWFN 8F5, Washington, DC 20555

96. R. E. Wilson, EG\&G Rocky Flats, Inc., P.O. Box 464, Building 886, Golden, CO 80402-0464

97. C. J. Withee, Office of Nuclear Material Safety \& Safeguards, U.S. Nuclear Regulatory Commission, MS TWFN 8F5, Washington, DC 20555 


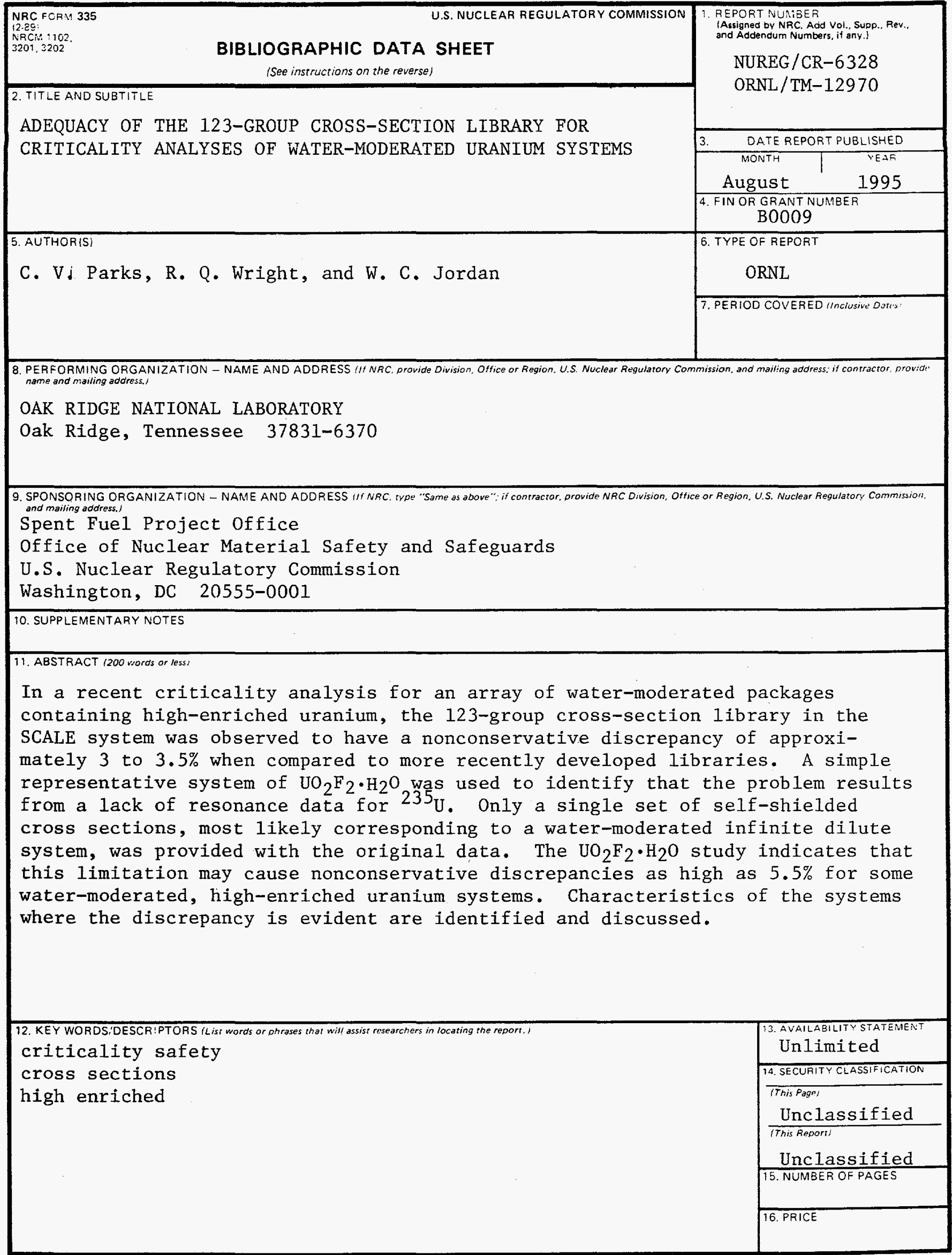

